\title{
Students' Habits Appear Captured by WhatsApp
}

\author{
Simon Bheki. Khoza ${ }^{1}$ \\ 1. Discipline of Curriculum Studies \& Educational Technology, School of Education, University of KwaZulu-Natal, \\ Durban, South Africa \\ Correspondence: Simon Bheki. Khoza, Discipline of Curriculum Studies \& Educational Technology, School of \\ Education, University of KwaZulu-Natal, Durban, South Africa
}

Received: July 10, 2020

Accepted: November 9, 2020

Online Published: November 16, 2020

doi:10.5430/ijhe.v9n6p307

URL: https://doi.org/10.5430/ijhe.v9n6p307

\begin{abstract}
Exploring students' habits of using WhatsApp is important: such introspection helps students to reflect, and improve their actions. Habits are subconscious thoughts that drive students, for example, to use WhatsApp, even without concentrating on their learning actions. Habits are formed after students have repeated the same action. Twelve students, registered for a Bachelor of Education degree in Mathematics Education at a university in South Africa, were selected to participate. The objective of this study was to understand students' habits of using WhatsApp in the learning of mathematics. Reflective activities, focus-group discussion, and one-on-one semi-structured interviews, framed by interpretive case study, were used for data production. The students' habits revealed that The Tree Three Rings Theory was useful when applied as the learning framework. Such application of the theory generated three categories of habits of WhatsApp usage. Categories were social, discipline/disciplinary, and personal habits. The university at which these students were registered prescribed Moodle as the learning management system (LMS). However, the students mostly used WhatsApp. As a result, they used WhatsApp even during face-to-face classes. It appeared that students had been 'captured' by WhatsApp, using it as their 'master', instead of using it as both their 'master' and 'servant'. The study concluded that, although there were elements of both personal and discipline habits, the social habits drove the learning. Consequently, this study recommends that students should reflect; using social, discipline, and personal actions as taxonomies of education habits, in order to address societal, individual, and the mathematics education needs.
\end{abstract}

Keywords: Digital technologies, discipline, habits, personal, social, WhatsApp

\section{Introduction}

In 2007, Jan Koum and Brian Acton, employed by Yahoo, left the company. In 2009, the erstwhile employees introduced WhatsApp as a communication tool for Smartphone and other mobile phone users. WhatsApp has become one of the most popular social network sites (SMSs) for the Fourth Industrial Revolution (4IR). WhatsApp is number three in terms of the number of users after YouTube (number two), and Facebook (number one) (Khoza, 2020; Mpungose, 2020a; Simon, 2020). WhatsApp took students by surprise while they were still enjoying the use of other SMSs such as Facebook, YouTube, inter alia. WhatsApp, the name, comes from the English colloquial expression "what's up?", meaning "what's new, or what's happening?". WhatsApp is one of the most popular application software, allowing students to exchange instant messages, videos, photos, and audio clips with one another. Students also use WhatsApp for free video and telephone calls when they are connected to the Internet. When students use WhatsApp activities, they develop new habits (habitual actions). Habits are subconscious thoughts that often drive students to use WhatsApp, without concentrating on their learning behaviour. Habits are formed after students have repeated the same WhatsApp actions even once. Habits are categorised into socialization or social, discipline, or qualification; and personal or subjectification habitual actions (Biesta, 2015; Khoza, 2019; Mpungose, 2020b). WhatsApp has changed learning to social learning. Such has promoted social habits that help students to address societal needs, through new, group-developed skills (Anaraki \& Babalhavaeji, 2013). Although socialization habits drive the learning, learning management systems (LMSs) such as Modular Object-Oriented Dynamic Learning Environment (Moodle) and others maintain and continue with the content-centred approach that promotes discipline habits, addressing discipline needs. In other words, today, learning is dominated by a contestation between social and discipline habitual actions, which focuses on societal skills (psychomotor domain), and/or academic achievements (cognitive domain). However, what seems to be missing in the literature as the cause of concern, is a discussion on the use of WhatsApp to promote personal or pragmatic habitual actions. Personal 
habitual actions help students to find and understand their identities through the strengths of both social and discipline habits, thereby addressing their personal and education needs (Conole, De Laat, Dillon, \& Darby, 2008; Fichten, Asuncion, \& Scapin, 2014; Mpungose, 2020c). As a result, it is still not known what promotes important values required by students (affective domain, personal identities, or self-actualization) in order to learn better. This suggests that there is a need for studies to be conducted on the use of WhatsApp in order to explore the habits or values that promote good education. As such, the next section presents the literature review on WhatsApp and its habits.

\section{Habits that Emerge from WhatsApp Usage}

On the one hand, social habits are formed by the usage of WhatsApp, as noted on the competence-based curriculum (Budden, 2017; Mpungose \& Khoza, 2020a; Pather, 2017). The competence-based curriculum is a plan of learning driven by students' experiences, that reflects students' societal needs and achievement of learning outcomes (Khoza, 2017; Kisaka, 2018). Alaidarous and Madini (2016) conducted a study on students' perceptions of social media in learning that promoted habitual actions. The study established that students used social media such as WhatsApp as a platform on which to share their experiences, gaining membership of various social groups interested in the achievement of group outcomes. In support of this study, AlDahdouh (2018) as well as Khoza and Biyela (2020) established that, when students are engaged in WhatsApp activities, they generate content of learning before they achieve learning outcomes. Content is what they share after they have engaged in WhatsApp activities in order to achieve learning outcomes, fulfilling students' goals. When students are assessed, they are assessed on what they have achieved (outcomes). Such assessment does not necessarily consider what students should have achieved: content is not prescribed, rather, it is generated from the activities (Bailey \& Garner, 2010; Khoza \& Manik, 2015). Students learn to support one another, become group members, understanding practices of various societies represented by group members, acquiring skills to address needs of the various societies (Mabuza \& Khoza, 2019; Makumane \& Khoza, 2020). This suggests that students' habits that drive their actions are based on group identities. Students become good at working with different societies (social habits). Achieving any pass mark is good for students when they are driven by social habitual actions. Students generate their content of achieving learning outcomes based on their experiences as group members (Dlamini, 2018; Shoba, 2018). Students do not necessarily target high marks - their aim, in most cases, is to gain a pass mark. However, other studies (Makumane, 2018; Mpungose, 2020d; Sodje, 2018) are of the view that, although students may have sustainable projects through supporting one another, social habits produce students who are highly impatient, group dependent, and expect handouts from other people. It is easy for students to fall into the trap of being 'captured' (respecting the groups or people in such a way that they act on group opinions without questioning or evaluating them) by other people or groups especially through WhatsApp. These studies point to discipline or qualification habits as a solution to the weaknesses of social habits.

On the other hand, discipline habits have been formed by the use of WhatsApp, based on the performance curriculum (Bosch, 2009; Bush, 2012; Sodje, 2018). The performance curriculum is driven by prescribed content that must be mastered by students in order to pass their courses (Hoadley, 2018; Mpungose \& Khoza, 2020b; Tyler, 2013). Objectives, as the short-term goals, are used to divide the content into small, manageable parts or chunks, that teachers wish students to achieve. The performance curriculum produces discipline habits, being content-centred in nature (Dennis, 2014; Khoza, 2019). Budden (2017) conducted a case study which established factors that informed the students' use of WhatsApp in learning. The study concluded that, while the course content, objectives, and activities were among the most important factors that promoted professional (discipline) habitual actions, summative assessment demanded that students be strict in mastering the course content. The students were aware that they would be assessed and judged on content that had not yet been mastered. As a result, they were strict in terms of mastering the content through the prescribed objectives and activities, without any deviation before the assessment took place. This study was supported by other studies (Dlamini, 2018; du Preez, 2017; Kirschner \& Karpinski, 2010; Mpungose, 2020d) also establishing that students are forced by summative assessment to follow strictly prescribed structures in learning. Such a response appears in students wishing to be in line with their teachers' expectations, passing their courses with distinction as their main goal. This suggests that, in the development of disciplinary/discipline habitual actions, students start their learning by knowing the prescribed assessment strategies. This occurs before students engage other factors, in order to align them with the relevant prescribed assessment strategies. One of the challenges of discipline habits is that students become discipline dependent: they always expect prescribed structures when they are given tasks to perform (Kamahina, Yakovenko, \& Daibova, 2019; Khoza \& Manik, 2015; Kisaka, 2018). Consequently, they tend to limit themselves within the prescribed structures, without going beyond the structures in order to produce new innovations through their creativity. 
The discussions of social and discipline habits reveal a need for a neutral platform of habits created through the strengths of disciplinary and social habits. A new, emerging category of habits is personal or pragmatic habits, that may address the needs of individual students by drawing on the strengths of both the social and discipline habits (Czerniewicz, 2018; Ilonga, Ashipala, \& Tomas, 2020; Khoza, 2013). Studies (Khoza, 2013; Khoza \& Manik, 2015; Mpungose, 2018) are of the view that students should learn with the aim of finding and understanding their identities through relevant theories such as The Tree Three Rings Theory (TTTRT) (Khoza, 2013) and others, before they attempt to address discipline or societal needs, in order to have control over WhatsApp and other digital technologies. In this way, students become digital natives or residents (becoming fluent in using digital technologies) (Czerniewicz, 2018; Prensky, 2001). It is for this reason that TTTRT was used as the theoretical framework for this study.

TTTRT is based on seven principles that must be observed by digital technology (WhatsApp) users, in order to positively control the learning process (Khoza, 2013). The principles are definition of students' behaviourism, constructivism, cognitivism, search engines, Learning Management Systems (LMSs), and designing of websites. Students should be defined and understood in terms of their needs, so that WhatsApp activities are tailored to students' needs. The role of behaviourism, constructivism, and cognitivism should be defined and understood in terms of their strengths before the use of WhatsApp, in order to generate discipline, and social and personal habits that address discipline, social, and personal needs. WhatsApp should be used in such a way that it plays the role of an LMS, a search engine, or bespoke website that accommodates digital technologies with their theories, in order to align WhatsApp theories with diverse needs (Khoza, 2020). Although this theory has only be used in a few studies, it fits the purpose of this study in interrogating the issues of behaviourism (discipline habits), constructivism (social habits), cognitivism (personal habits) and the three rings/circles that interrogate WhatsApp. Therefore, the TTTRT was employed for this study, based on the following purposes/objectives, having research questions and research design aligned with methodology of this study in order to generate relevant findings.

\section{Purpose/Objective and Research Questions of the Study}

The purpose and objective of the study is to explore and understand students' habits of using WhatsApp in the learning of mathematics at a university in South Africa. This study was driven by the following research questions:

- What are students' habits of using WhatsApp in the learning of mathematics at a university in South Africa?

- Why do students have particular habits in using WhatsApp for learning mathematics at a university in South Africa?

\section{Research Design and Methodology}

This study applied a qualitative, interpretive case study of twelve students (fourth-year students), registered for a Bachelor of Education degree in Mathematics Education at a university in South Africa. The students were purposively selected to participate in this study. I applied qualitative interpretive case study because of its reality nature, which suggests multi-truths that are generated through dialogues between the researchers and participants (Ramrathan, 2017; Yin, 2011). This helped me to explore and understand students' habits of using WhatsApp through their reflections; such being exploratory and descriptive in nature (Creswell, 2014; Esau, 2017). I used purposive sampling through convenience sampling. I selected the most accessible twelve mathematics students, whom I introduced to the use of Moodle before they used WhatsApp. I wrote letters to the gatekeeper (their university registrar) to explain the nature of the study (in terms of confidentiality, anonymity, voluntariness, and other ethical principles) in order to gain permission before I invited the students to participate. I replaced their real names with pseudonyms, represented by symbols from P1 to P12 (Table 1) in order to address the ethical principle of anonymity. Table 1 presents the profiles of the participants, which highlights that the participants were from 22 to 25 years old. There were seven males and five females. Ethnically, there were five African, two Coloured, three Indian, and two White students. Experience of first use of WhatsApp was from 4 to 6 years of age. 
Table 1. Student Profiles

\begin{tabular}{lllll}
\hline Name & Gender & Age & Race & WhatsApp Experience in years \\
\hline P1 & Female & 22 & White & 5 \\
P2 & Female & 22 & White & 5 \\
P3 & Male & 22 & African & 4 \\
P4 & Male & 23 & African & 5 \\
P5 & Male & 23 & African & 5 \\
P6 & Female & 23 & African & 6 \\
P7 & Male & 24 & Indian & 6 \\
P8 & Male & 24 & Coloured & 5 \\
P9 & Female & 25 & Coloured & 6 \\
P10 & Female & 25 & Indian & 6 \\
P11 & Male & 25 & Indian & 5 \\
P12 & Male & 25 & African & 6 \\
\hline
\end{tabular}

\section{Data Generation and Analysis}

Reflective activities, focus-group discussion (using Zoom), and one-on-one semi-structured interviews (using Skype), were used for data production. Each of these methods was administered twice in order to triangulate the data. Reflective activities were in the form of a questionnaire, with open-ended questions framed by TTTRT principles. Reflective activities were mostly used for Research Question One (what are students' habits...?). Such reflection is of benefit in addressing descriptive questions to which responses are written by participants (Babbie \& Mouton, 2010; Khoza, 2019). Focus-group discussion, and one-on-one semi-structured interviews as the conversations between the researcher and participants, took approximately one hour each. Such communication helped me to achieve rich and in-depth descriptions of the phenomenon, through probing and rephrasing the questions, in order to secure responses from participants who tended to avoid questions (Deakin \& Wakefield, 2013; Ramrathan, 2017). The following were the main questions for the three methods, based on TTTRT:

- What role do you play when you use WhatsApp in learning mathematics?

- What prescribed instructions or content do you follow in using WhatsApp in learning mathematics?

- What activities do you involve when you use WhatsApp in learning mathematics?

- What values do you achieve when you use WhatsApp in learning mathematics?

- What search engines do you access when you use WhatsApp in learning mathematics?

- What LMSs do you access when you use WhatsApp in learning mathematics?

- What platforms or websites do you design or work with when you use WhatsApp in learning mathematics?

Guided analysis was used in this study, because such is capable of dealing with both the inductive (qualitative) and deductive (quantitative) processes (Nieuwenhuis, 2016; Samuel, 2009). I started the data generation and analysis using data from the principles of TTTRT (deductive), combining such with data that emerged from the participant responses to produce themes and categories that frame the findings. Guided analysis helped me to achieve the issues of trustworthiness (Guba \& Lincoln, 2005).

Trustworthiness was addressed in terms of confirmability (neutrality - all participants knew me and were aware of the issues of ethics), credibility (truth value - audit trail and tape recorder), dependability (consistency - direct quotations from the participants), and transferability (applicability - by providing sufficient details of the relevant context). However, the limitation of the study was that it did not include the quantitative data which may be of interest to readers interested in positivism. However, the findings of the qualitative data are presented in detail, in order to be readable, and to accommodate readers from various paradigms.

\section{Research Findings}

The findings presented in Table 2 are framed by four themes (social, discipline, personal, and education habits - see Figure 1 as well) with relevant categories. Each of the findings presented under the themes was answered (in writing) 
through the reflective activities, and confirmed/triangulated by means of the focus-group discussions and interviews. I also substantiated the findings by means of discussions in order to re-contextualise them with relevant literature.

Table 2. Findings

\begin{tabular}{lcl}
\hline THEMES & CATEGORIES \\
\hline THEME 1: Social habits & $\bullet$ & WhatsApp activities \\
THEME 2: Discipline habits & $\bullet$ & Search engines \\
& $\bullet$ & Instructions and content \\
THEME 3: Personal habits & $\bullet$ & Role of new identities \\
& $\bullet$ & Personal websites \\
THEME 4: Education habits & $\bullet$ & Values as function of education
\end{tabular}

\section{Discussion of Findings}

\subsection{THEME 1: Social Habits}

\subsubsection{WhatsApp Activities}

AlDahdouh (2018) supports the notion of activities that are driven by digital technology resources, such as WhatsApp, as one of the important elements of the Fourth Industrial Revolution (4IR). It becomes important for students to understand and take responsibility for their WhatsApp activities, because such activities have the power to produce particular habits. One of the most important WhatsApp activities is the "exchange of videos because it is not easy to email them to friends and all friends use WhatsApp... Although most of the videos we exchange are for entertainment, they do help us to distress before we learn Mathematics which demand a lot of concentration..." (P4, and supported by others). The participants seemed to enjoy video-call activity because they can see one another when they call. "I use video calls to call my friends more than the normal calls because it help me to make sure that I am talking to the right person... Social media has too many scams, as a result it is better to communicate with friends using both text and video calls..." (P2, and others agreed).

These accounts suggest that the activities help them with socialization, making friends, and become aware of the cyberbullying side of social media. According to Smit (2015), when WhatsApp is used for socialization, students become vulnerable to cyberbullies. Such bullies use fake numbers to create WhatsApp accounts to be used for scams. However, although the participants endorsed their actions of using WhatsApp to develop social habits, they were aware of the cyberbullying.

\subsubsection{Search Engines}

"...although we use search engines like Google Scholar and others when we search for module information, our WhatsApp discussions are powerful enough to help us to identify relevant information..." (P4, and others agreed). This suggests that the students were influenced by the use of WhatsApp to limit their use of search engines in searching for literature or sources of information.

\subsection{THEME 2: Discipline Habits}

\subsubsection{Instructions and Content}

According to Bansilal (2015), it is important that students have positive perceptions, and that they understand mathematics instructions and content when they use digital technology (such as WhatsApp) in learning, in order to master the ideology of mathematics. The ideology in taking mathematics is the belief by students that they have joined the realms of the intellectuals: mathematics is claimed to be a subject for gifted students. The participants had two WhatsApp groups each. One was compulsory for the mathematics class (discipline); and the other one was for friends (social). "We only use class WhatsApp for instructions from the lecturers in order to discuss the content of Mathematics and exchange Mathematics videos and documents... This has helped us to learn how to concentrate on one content for a long time [drilling lessons] until you get it 100\% correct... Unlike in the other subjects where you can have more than one correct answer if you can justify... Mathematics force us to learn to concentrate and search for the correct answer... otherwise you cannot be good in Mathematics" (P12, and others agreed). "When we started our first year we were 40 but now we are 12 because others dropped out of the module as they could not cope with the level of concentration demanded by our lecturers especially through WhatsApp... It was difficult for us too but 
we had to learn to be strong for the direct and harsh instructions that demanded us to master the content without any deviation in order to pass Mathematics with high mark..." (P6, and others agreed).

The above suggests that participants used their class WhatsApp accounts to develop mathematics discipline habits which are promoted through direct instructions, if learning intention is to achieve high marks (Dowling \& Wilson, 2017). The direct instructions are used to indicate to students what exactly is missing, in order for the students to correct such, achieving one hundred per cent (Anaraki \& Babalhavaeji, 2013; Khoza, 2020; Zaitun, 2010). An example of a direct instruction is that when a student writes $X+2 X=X^{2}$, the lecturer will simply state: 'the answer is wrong', not putting this more sensitively. The responses indicate that the participants generated strong habits of coping with mathematics no matter what, because they intended to complete the course with high marks. They learned to ignore direct comments, not taking them personally.

\subsubsection{Moodle}

"We should be using Moodle as our university prescribed learning management systems, but we find it easier to access WhatsApp than Moodle... Since we started to use WhatsApp, we only use Moodle for discussion forums where we do PowerPoint presentations, module content from different linked sources, and module evaluation forms..." (P3, and others agreed).

This suggests that WhatsApp usage motivated students to develop new habits; even limiting themselves to usage of prescribed digital resources. The use of WhatsApp generates new habitual ways of dealing with their activities. This further suggests that the discipline habits (in their efforts to replace official Moodle with WhatsApp social network) have introduced students to new personal habits.

\subsection{THEME 3: Personal Habits}

\subsubsection{Role of New Identities}

Participants were required to perform a task on transformation geometry in which 'reflection' is one of the principles. Students were also required to use this principle of reflection to reflect on their role of learning mathematics supported by WhatsApp. The students started to question their actions, reflecting on their personal identities and their roles in learning. "We are playing active roles in our learning because we now know exactly when we should be professional (class WhatsApp) and also when we should socialize (social WhatsApp)... These roles are now performed without any serious concentration because we used to have a time-table for the class WhatsApp which was demanding us to spend a minimum of ten hours each day talking about Mathematics in order generate Mathematics habits or culture..." (P1, and others agreed). "I can say I know my identity and my personal needs through reflections... It was even easy for us to respond to you when you asked us to reflect because reflections are part of Mathematics... Reflections also help us to always question our habits in order to alter all habits that are no longer good for our personal identities or needs..." (P8, and others agreed).

These accounts suggest the importance of self-reflection that fosters awareness in students of their actions. According to Khoza (2017) and Maxwell (2013), when students reflect on discipline - past, social - present, and personal - future, they achieve better results. Students are able to identify challenges, addressing them before they affect their performance. Some students had even had a personal website before they were attracted to WhatsApp.

\subsubsection{Personal Websites}

"I used to have weblogs and Facebook pages where I used to display both my module and social activities... Now I do this much better with WhatsApp ..." (P1, and P2, P5, P8 agreed). Other participants had not had personal websites: WhatsApp was the first personal platform they had added to the prescribed Moodle. This suggests that WhatsApp came to students as a powerful force that transformed them, offering new habits. Such new habits include education habits.

\subsection{THEME 4: Education Habits}

\subsubsection{Values as Function of Education}

Social, discipline, and personal habits should always be interrogated by reflections, in order to produce values that address students' needs before they contribute towards their societal and discipline needs (Khoza, 2018; Maxwell, 2013). Among the values that were achieved or acquired by the students were integrity, independence, collaboration, pre-eminence, inspiration, relevance, diversity, adaptability, and others. In the process of using WhatsApp in learning mathematics "we learned to respect, be honest, and be fair and also care for other human beings...[integrity]" (P5, and others agreed). "...we are able to work confidently within and outside the groups... [independence]" (P3, and others agreed). "...we collaborate with other students, lecturers and community members 
to maximize our professional, societal, and personal development... [collaboration]" (P6, and others agreed). "...uphold outstanding standards of performance in our actions... [pre-eminence]" (P7, and others agreed). "We encourage and motivate other students and friends to practise Mathematics every day in order to enjoy it like us... [inspiration]" (P11 and others agreed). "We endorse our academic programmes, social activities, and research activities... [relevance]" (P10, and others agreed). "We unlock a range of WhatsApp interactions with a wide variety of backgrounds, and cultures... [diversity]" (P9, and others agreed). "...we acknowledge our ever-changing knowledge, skills and values in order to adapt to any environment ... [adaptability]" (P8, and others agreed).

These accounts suggest the importance of education in promoting life values that are required by disciplines, societies, and students themselves. The findings support the claims by Biesta (2015) of good education as the function of promoting values (habits) that are informed by qualification (discipline), socialization (social), and subjectification (personal) domains (actions). In other words, these twelve students were exposed to good education (through WhatsApp). The platform (WhatsApp) used these domains as taxonomies of learning that promoted many different values required by the students, societies, and disciplines.

\section{Conclusion}

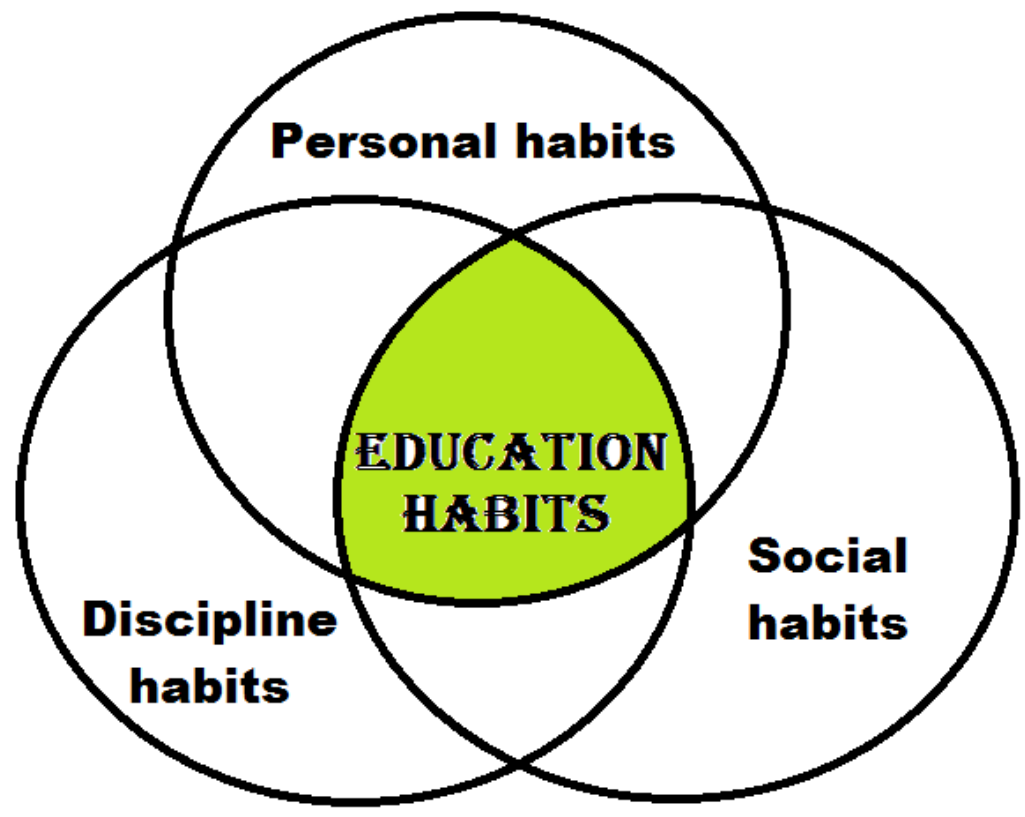

Figure 1. Educational habits for WhatsApp

Figure 1 summarises and concludes the findings for the study. In conclusion, Khoza (2018) and Mpungose (2020c) lament that there is limited literature on what prepares students with education habits that are relevant to the Fourth Industrial Revolution (4IR). Such paucity of relevant literature encouraged me to conduct this study. This is supporting Biesta (2015), in that it is still not known what promotes values such as patience, and other intrinsic values of learning. Biesta (2015), therefore, recommended that education should be the dual responsibility of students and their lecturers. Such dual responsibility would ensure that the three educational domains (qualification/discipline, socialization/social and subjectification/personal) are equally applied in learning.

The importance of dual responsibility was evident in this study. Students had a class WhatsApp, which was used strictly by the students and their lecturers for mathematics only. This helped students to acquire integrity, independence, collaboration, pre-eminence, inspiration, relevance, diversity, and adaptability as their most important lifestyle habits. The students worked as a strong team; some twenty-eight students of an original forty students dropped out of the course. The question must surely therefore be asked: what should be used in order to foster these values (habits) for the majority of our students? What has been witnessed in this study is that only the minority (12) benefitted from the use of WhatsApp in learning mathematics. This suggests that there should be another study conducted elucidating how these numbers can be turned around so that the majority of students can benefit by mathematics education.

On the one hand, Khoza (2019) and Maxwell (2013) strongly believe that reflection, as a process of interrogating one's past, present, and future experiences, can be a better resource for supporting both lecturers and students in 
finding and understanding their identities, based on discipline, societal/social, and personal needs. On the other hand, Singhal and Rogers (1999) propose the use of Entertainment-Education Theory (EET), allowing students to learn while they play on WhatsApp. While EET may be good at keeping students in their courses, it takes much time to achieve worthwhile education values/habits. Unfortunately, students are afforded only one semester in which to achieve such values. It was clear from this study that the students knew the values that drove their habits (habitual actions) through self-reflection, after they had been instructed or given tasks by their lecturer. This suggests the importance of self-reflection that must be promoted, in order to help students understand what constitutes their habitual actions of learning.

Clearly, WhatsApp self-reflection helped students to understand their needs; students developed coping strategies as a team. The coping strategies of acquiring the pursued values helped strengthen students, who understood that direct, if harsh-sounding instructions were used in order to help them to come to terms with their personal identities. When students answered the questions in this study (reflective activity, focus-group discussions, and one-on-one semi-structured interviews), they gave very similar responses, and were able to support one another.

Although self-reflection is important, such elements addressing the psyche sometimes discourage students. Many students are highly dependent on the attitudes and responses of others to each aspect of learning. They do not take time to be alone (me time) in order to interrogate their habits or habitual actions (Akbari, 2007; Khoza, 2017). It was evident from this study that students appear dependent on WhatsApp groups (class and friends), almost as though they could not learn without WhatsApp. Students seemed to be 'captured' (no power over it, loss of control) by WhatsApp. Students subscribed to and kowtowed to it as their 'master' (used without identified reasons and goals), rather than as their 'servant' (used without identified reasons and goals) (Khoza, 2018). They may rather use it as both their master and servant than as the master only. Therefore, reflections need thorough planning and administration to balance social, discipline, and personal actions, in order to accommodate students from a wide variety of action or domain types. In using positive reflection, we may be able to incorporate educational habits and needs into social, discipline, and personal habits and needs, giving such a prominent position (Figure 1).

However, it seems that there was another level of "natural actions of using WhatsApp" that both subconsciously and unconsciously drove the participants. Their body systems (unconscious) and habits (subconscious) helped them to adapt and become problem-centred in their teaching. Their mobile devices with WhatsApp were used in most of their learning and personal activities. The devices seemed to naturally connect and work for the participants even when they were not aware of how to learn under the COVID-19 challenges. These are qualities of natural actions to cope within the uncertainty (COVID-19 and lockdown) and 4IR (Mpungose \& Khoza, 2020a).

\section{Acknowledgement}

Editor (Lydia Weight lydiaweight@gmail.com) for editing the article and the participants for participating.

Funding: Dr Blossom Bulelwa Piliso's Award for The Conversation Africa Competition from the Witwatersrand University CoE-Human Development and Tamsen Rochat as well as DST-NRF Centre of Excellence in Human Development.

\section{References}

Akbari, R. (2007). Reflections on reflection: A critical appraisal of reflective practices in L2 teacher education. System, 35(2), 192-207. https://doi.org/10.1016/j.system.2006.12.008

Alaidarous, K., \& Madini, A. A. (2016). Exploring EFL Students' Perception in Blended Learning Environment in Saudi Technical Education Context. International Journal of Educational Investigations, 3(6), 69-81. http://ijeionline.com/attachments/article/55/IJEI.Vol.3.No.6.04.pdf

AlDahdouh, A. A. (2018). Jumping from one resource to another: how do students navigate learning networks? International Journal of Educational Technology in Higher Education, 2018(1), 1-17. https://doi.org/0.1186/s41239-018-0126-x

Anaraki, L. N., \& Babalhavaeji, F. (2013). Investigating the awareness and ability of medical students in using electronic resources of the integrated digital library portal of Iran: A comparative study. The Electronic Library, 31(1), 70-83. https://doi.org/10.1108/02640471311299146

Babbie, E., \& Mouton, J. (2010). The practice of social research. Cape Town: Oxford University Press.

Bailey, R., \& Garner, M. (2010). Is the feedback in higher education assessment worth the paper it is written on? Teachers' reflections on their practices. Teaching in Higher Education, 15(2), 187-198. https://doi.org/10.1080/13562511003620019 
Bansilal, S. (2015). Exploring student teachers' perceptions of the influence of technology in learning and teaching mathematics. South African Journal of Education, 35(4), 1-8. https://doi.org/10.15700/saje.v35n4a1217

Biesta, G. (2015). What is Education For? On Good Education,Teacher Judgement, and Educational Professionalism. European Journal of Education, 50(1), 75-87. https://doi.org/10.1111/ejed.12109

Bosch, T. E. (2009). Using online social networking for teaching and learning: Facebook use at the University of Cape Town. Communicatio: South African Journal for Communication Theory and Research, 35(2), 185-200. https://doi.org/10.1080/02500160903250648

Budden, R. (2017). Exploration of factors that inform curriculum studies students to use e-resources in conducting Masters of Education dissertations at a South African university. (Doctor of Philosophy Full research), University of KwaZulu-Natal, Durban. (1)

Bush, T. (2012). International perspectives on leadership development: making a difference. Professional Development in Education, 38(4), 663-678. https://doi.org/10.1080/19415257.2012.660701

Conole, G., De Laat, M., Dillon, T., \& Darby, J. (2008). 'Disruptive technologies','pedagogical innovation': What's new? Findings from an in-depth study of students' use and perception of technology. Computers \& Education, 50(2), 511-524. https://doi.org/10.1016/j.compedu.2007.09.009

Creswell, J. W. (2014). Qualitative inquiry and Research Design: Choosing among five approaches (3 ed.). California: SAGE Publications, inc.

Czerniewicz, L. (2018). Inequality as Higher Education Goes Online. In N. B. Dohn, S. Cranmer, J. A. Sime, M. de Laat, \& E. Ryberg (Eds.), Networked Learning: Reflections and Challenges. Heidelberg: Springer Verlag.

Deakin, H., \& Wakefield, K. (2013). Skype interviewing: Reflections of two PhD researchers. Qualitative Research, $O(0), 1-14$. https://doi.org/10.1177/1468794113488126

Dennis, R. (2014). Improvised performance: Nurturing natural leadership. Journal of Organisational Transformation \& Social Change, 11(2), 108-124. https://doi.org/10.1179/1477963313Z.00000000016

Dlamini, M. (2018). Exploring formative assessment practices in Context-Based Science Curriculum in Swaziland: A case of Form 2 Junior Secondary School Science. (Doctor of Philosophy), University of KwaZulu-Natal, Durban.

Dowling, R., \& Wilson, M. (2017). Digital doctorates? An exploratory study of PhD candidates' use of online tools. Innovations in Education and Teaching International, 54(1), 76-86. https://doi.org/10.1080/14703297.2015.1058720

du Preez, P. (2017). Classical theories and theorists of curriculum studies. In L. Ramrathan, L. Le Grange, \& P. Higgs (Eds.), Education Studies: for Initial Teacher Development (pp. 95-111). Cape Town: Juta \& Company.

Esau, O. (2017). Emancipatory action research. In L. Ramrathan, L. Le Grange, \& P. Higgs (Eds.), Education Studies: for Initial Teacher Development (pp. 444-455). Cape Town: Juta \& Company (Pty) LTD.

Fichten, C. S., Asuncion, J., \& Scapin, R. (2014). Digital Technology, learning, and postsecondary students with disabilities: where we've been and where we're going. Journal of Postsecondary Education and Disability, 27(4), 369-379.

Guba, E. G., \& Lincoln, Y. S. (2005). Paradigmatic controversies, contradictions, and emerging Confluences. In N. K. Denzin \& Y. S. Lincoln (Eds.), Handbook of qualitative research (3 ed., pp. 191-216). London: SAGE Publications.

Hoadley, U. (2018). Pedagogy in Poverty: Lessons from Twenty Years of Curriculum Reform in South Africa. London and New York: Routledge - Taylor \& Francis Group. https://doi.org/10.4324/9781315680927

Ilonga, A., Ashipala, D. O., \& Tomas, N. (2020). Challenges Experienced by Students Studying through Open and Distance Learning at a Higher Education Institution in Namibia: Implications for Strategic Planning. International Journal of Higher Education, 9(4), 116-127. https://doi.org/10.5430/ijhe.v9n4p116

Kamahina, R. S., Yakovenko, T. V., \& Daibova, E. V. (2019). Teacher's Readiness to Work under the Conditions of Educational Space Digitalization. International Journal of Higher Education, 8(7), 79-83. https://doi.org/10.5430/ijhe.v8n7p79

Khoza, S. B. (2013). Can they change from being digital immigrants to digital natives? Progressio, 35(1), 54-71. 
Khoza, S. B. (2017). Master of Education Students' Reflections: Which Curriculum Reasons Are Promoted or Limited by Skype Resources? Progressio: South African Journal for Open and Distance Learning Practice, 39(2), 1-19. https://doi.org/10.25159/0256-8853/2405

Khoza, S. B. (2018). Can Teachers' Reflections on Digital and Curriculum Resources Generate Lessons? Africa Education Review, 1(2018), 1-16.

Khoza, S. B. (2019). Lecturers' Reflections on Curricular Spider Web Concepts Transformation Strategies. In E. N. Ivala \& C. L. Scott (Eds.), Transformation of Higher Education Institutions in Post-Apartheid South Africa (Vol. 1, pp. 15-26). New York: Routledge - Taylor \& Francis Group. https://doi.org/10.4324/9781351014236-2

Khoza, S. B. (2020). Academics' "Why" of Knowledge-Building for the Fourth Industrial Revolution and COVID-19 Era. International Journal of Higher Education, 9(6), 247-258. https://doi.org/10.5430/ijhe.v9n6p247

Khoza, S. B., \& Biyela, A. T. (2020). Decolonising Technological Pedagogical Content Knowledge of First Year Mathematics Students. Education and Information Technologies, 25(4), 2665-2679. https://doi.org/10.1007/s10639-019-10084-4

Khoza, S. B., \& Manik, S. (2015). The Recognition of 'Digital Technology Refugees' amongst Post Graduate students in a Higher Education Institution. Alternation, 17(2015), 190-208.

Kirschner, P. A., \& Karpinski, A. C. (2010). Facebook and academic performance. Computers in Human Behavior, 26(6). https://doi.org/10.1016/j.chb.2010.03.024

Kisaka, S. T. (2018). An Exploration of the Use of Moodle in Teaching MED Students at a University in Kenya. (Doctor of Philosophy Full Thesis), University of KwaZulu-Natal, Durban.

Mabuza, D. C., \& Khoza, S. B. (2019). Educators' reflections of the instructional time in JC integrated consumer science curriculum. International Journal of Home Science, 5(1), 1-7.

Makumane, M. A. (2018). Educators' Enactment Strategies of the French Integrated Curriculum: An Action Research of Lesotho Educators. (Doctor of Philosophy Full Thesis), University of KwaZulu-Natal, Durban.

Makumane, M. A., \& Khoza, S. B. (2020). Educators' Reasonings and their Effects on Successful Attainment of Curriculum Goals. South African Journal of Higher Education, 34(2), 95-111. https://doi.org/10.20853/34-2-3428

Maxwell, T. W. (2013). A Model for Reflection to Be Used in Authentic Assessment in Teacher Education. Journal of the International Society for Teacher Education, 17(1), 8-17.

Mpungose, C. B. (2018). Exploring lecturers' reflections on the use of Moodle to teach Physical Sciences at a South African University. (Doctor of Philosophy), University of KwaZulu-Natal, Durban.

Mpungose, C. B. (2020a). Are Social Media Sites a Platform for Formal or Informal learning? Students' Experiences in Institutions of Higher Education. International Journal of Higher Education, 9(5), 300-311. https://doi.org/10.5430/ijhe.v9n5p300

Mpungose, C. B. (2020b). Beyond limits: Lecturers' reflections on Moodle uptake in South African universities. Education and Information Technologies, 2020(4), 1-20. https://doi.org/10.1007/s10639-020-10190-8

Mpungose, C. B. (2020c). Is Moodle a Platform to Decolonise the University Curriculum? Lecturers' Reflections. Africa Education Review, 17(1), 100-115. doi: https://doi.org/10.1080/18146627.2018.1479645

Mpungose, C. B. (2020d). Is Moodle or WhatsApp the preferred e-learning platform at a South African university? First-year students' experiences. Education and Information Technologies, 25(2), 927-941. https://doi.org/10.1007/s10639-019-10005-5

Mpungose, C. B., \& Khoza, S. B. (2020a). Digitalised Curriculum to the rescue of a Higher Education Institution. African Identities, 18(4), 1-21. https://doi.org/10.1080/14725843.2020.1815517

Mpungose, C. B., \& Khoza, S. B. (2020b). Postgraduate Students' Experiences on the Use of Moodle and Canvas Learning Management System. Technology, Knowledge and Learning, 28(4), 1-16. https://doi.org/10.1007/s10758-020-09475-1

Nieuwenhuis, J. (2016). Qualitative research designs and data-gathering techniques. In K. Maree (Ed.), First steps in research (3 ed., pp. 72-100). Pretoria: Van Schaik. 
Pather, R. (2017). Library spaces in higher education: exploring academics' understanding. (Doctor of Philisophy Full thesis), University of KwaZulu-Natal, Durban. (1)

Prensky, M. (2001). Digital natives, digital immigrants part 1. On the horizon, 9(5), 1-6. https://doi.org/10.1108/10748120110424816

Ramrathan, L. (2017). Educational Research: Key concepts. In L. Ramrathan, L. Le Grange, \& P. Higgs (Eds.), Education Studies: for Initial Teacher Development (pp. 403-418). Cape Town: Juta \& Company (Pty) LTD.

Samuel, M. A. (2009). On becoming a Teacher: Life history research and the force-field model of Teacher Development in Dhunpath, $R$. and Samuel, M.A. (Eds.). Life history research-Epistemology, methodology and representation. Rotterdam: Sense Publishers. https://doi.org/10.1163/9789087908584

Shoba, M. E. (2018). Exploring Teachers' Experiences of Teaching English-Speaking Skill to Second Language Learners in Three KwaNdengezi Township Primary Schools. (Doctor of Philosophy Full Thesis), University of KwaZulu-Natal, Durban.

Simon, K. (2020). Digital 2020 reports. $\quad$ Retrieved from https://wearesocial.com/blog/2020/01/digital-2020-3-8-billion-people-use-social-media

Singhal, A., \& Rogers, E. M. (1999). Entertainment-Education: A Communication Strategy for Social Change. New Jersey: Lawrence Erlbaum Associate Publishers.

Smit, D. M. (2015). Cyberbullying in South African and American schools: A legal comparative study. South African Journal of Education, 35(2), 1-11. https://doi.org/10.15700/saje.v35n2a1076

Sodje, P. E. (2018). Exploring the Use of Internet Resource/s in Learning Mathematics at a TVET College in South Africa. (Doctor of Philosophy), University of KwaZulu-Natal, Durban.

Tyler, R. W. (2013). Basic principles of curriculum and instruction. Illinois: University of Chicago press. https://doi.org/10.7208/chicago/9780226086644.001.0001

Yin, R. K. (2011). Qualitative Research from Start to Finish. New York: The Guilford Press.

Zaitun, A. B. (2010). Strategic Cooperation to Enhance Quality in Doctoral Supervision. Jazan: Naif Arab University For Security Science (NAUSS).

\section{Copyrights}

Copyright for this article is retained by the author(s), with first publication rights granted to the journal.

This is an open-access article distributed under the terms and conditions of the Creative Commons Attribution license (http://creativecommons.org/licenses/by/4.0/). 